\title{
Phytophthora nicotianae var. nicotianae on greenhouse tomatoes
}

\author{
Phytophthora nicotianae var. nicotianae na pomidorach szklarniowych
}

\author{
Leszek B. Orlikowski, Magdalena Ptaszek
}

\section{Summary}

Stem and root rot symptoms were noticed in two greenhouse farms on tomatoes planted in the 3rd decade of June, 2013. Diseased plants exposed suppressed growth and top wilting due to drastic decrease of water and poor transport of mineral salt. From diseased stem and root parts Phytophthora nicotianae var. nicotianae was isolated. The same species was also detected in cubs and stonewool mats. In laboratory experiments isolates of $P$. nicotianae var. nicotianae caused rotting of stem parts, leaf petioles, leaf blades and fruits regardless of tested cultivar. Necrosis spread even more than $8 \mathrm{~mm}$ per $24 \mathrm{hrs}$. Colonisation of tomato stem parts was observed at temperature range from 10 to $32.5^{\circ} \mathrm{C}$ as the optimum. In the greenhouse trials $P$. nicotianae var. nicotianae added to peat with infested stonewool caused wilting of 3-week-old tomato cultivar Admiro seedlings already after 3-day-growth and 5 days later most of plants wilted and died. The pathogen colonized stem base of seedlings on the length up to $30 \mathrm{~mm}$.

Key words: rot; stem; roots; Phytophthora; isolates; cultivars; colonization

\section{Streszczenie}

W 2 gospodarstwach szklarniowych na pomidorach sadzonych w 3 dekadzie czerwca 2013 roku stwierdzono objawy zgnilizny podstawy pędów oraz korzeni. W następstwie drastycznego ograniczenia przewodzenia wody $\mathrm{i}$ soli mineralnych dochodziło do zahamowania wzrostu pomidorów oraz więdnięcia ich wierzchołków. Z porażonych tkanek podstawy pędów oraz korzeni izolowano głównie Phytophthora nicotianae var. nicotianae. Gatunek ten stwierdzono również w kostkach oraz matach z wełny mineralnej. W doświadczeniach laboratoryjnych izolaty $P$. nicotianae var. nicotianae powodowały zgniliznę części łodyg, ogonków i blaszek liściowych oraz owoców, niezależnie od odmiany. Nekroza rozwijała się nawet ponad $8 \mathrm{~mm}$ na dobę. Kolonizację części łodyg pomidora stwierdzono w zakresie temperatur od 10 do $32,5^{\circ} \mathrm{C}$ jako optimum. W doświadczeniach szklarniowych gatunek $P$. nicotianae var. nicotianae wprowadzony do substratu torfowego, powodował więdnięcie 3-tygodniowych siewek pomidorów odmiany Admiro już po 3 dniach uprawy, a po 8 dniach niemal wszystkie rośliny zwiędły. Patogen kolonizował tkanki podstawy pędów na długości do $30 \mathrm{~mm}$.

Słowa kluczowe: zgnilizna; łodyga; korzenie; Phytophthora; izolaty; odmiany; kolonizacja

Instytut Ogrodnictwa

Konstytucji 3 Maja 1/3, 96-100 Skierniewice

leszek.orlikowski@inhort.pl 


\section{Wstęp / Introduction}

Price i Maxwell (1980) oraz Zinnen (1988) uważają, że gatunki rodzajów Pythium i Phytophthora, jako czynniki powodujące zgniliznę korzeni, stanowią największy problem w uprawie hydroponicznej roślin. Wśród nich Phytophthora nicotianae var. nicotianae Breda de Haan (= Pnn) jest jednym z bardzo groźnych czynników chorobotwórczych pomidorów (Weststejn 1973; Ho i wsp. 1984; Bruna i Tobar 2004). Nazwa gatunkowa P. nicotianae Breda de Haan pojawiła się w 1896 roku, a w ciągu następnego półwiecza gatunek oznaczano m.in. jako: $P$. melongenae, $P$. allii, $P$. terestris, $P$. parasitica var. rhei, $P$. jatrophae, $P$. tabaci, $P$. parasitica var. piperina, P. formosana (Erwin i Ribeiro 1996). W 1942 roku Sawada oznaczył ten gatunek jako $P$. lycopersici po jego izolacji z porażonych pomidorów (Erwin i Ribeiro 1996). W 1964 roku Waterhouse i Waterston oznaczyli ten gatunek jako $P$. nicotianae var. nicotianae Breda de Haan. Ich zdaniem Pnn jest sprawcą zgorzeli przedwschodowej, raka pędów, zgnilizny i zamierania korzeni oraz brązowych, koncentrycznych plam występujących na owocach. Grote i Claussen (2001) podają, że do ponad 72 rodzajów roślin żywicielskich, atakowanych przez ten gatunek, należą również pomidory, tytoń, awokado, rośliny ozdobne i drzewa. W opracowaniu Erwina i Ribeiro (1996) Pnn podawany jest jako patogen około 300 gatunków roślin. Zdaniem Grote i Claussen (2001), infekcja pomidorów przez Pnn i rozwój choroby uzależniony jest od: temperatury, niedoboru tlenu, produkcji etylenu i dwutlenku węgla w rizosferze oraz stopnia nawilgocenia podstawy pędu. Wydzielanie przez korzenie związków węgla i aminokwasów oraz zróżnicowana zawartość asymilatów w systemie korzeniowym i pędzie, zwłaszcza w okresie owocowania, zwiększa podatność roślin na omawianego patogena. Elena (2000) badając chorobotwórczość izolatów Pnn wykazała, że kultury z tytoniu nie były patogeniczne dla pomidorów, ale izolaty $\mathrm{z}$ innych żywicieli powodowały objawy chorobowe na tej roślinie. Opis choroby, głównie w oparciu o pracę Weststejna (1973), zawarty jest w opracowaniu Boczka i wsp. (1985). Możliwości ochrony pomidorów szklarniowych przed patogenami glebowymi, w tym zgnilizną pierścieniową powodowaną przez Pnn badał Ślusarski (2005), lecz autor nie podaje objawów chorobowych wywoływanych przez ten gatunek oraz rozwoju choroby. Mimo wzmianek o występowaniu i szkodliwości patogena w Polsce, dotychczas brakowało udokumentowanych danych dotyczących jego występowania oraz szkodliwości dla pomidorów.

Celem badań było określenie przyczyny choroby, jej rozwoju w zależności od źródła izolatów, odmian pomidorów, organów rośliny oraz temperatury.

\section{Materiały i metody / Materials and methods}

Objawy chorobowe na pomidorach i izolacja mikroorganizmów. W 2013 roku w 2 obiektach szklarniowych, specjalizujących się $\mathrm{w}$ uprawie pomidorów, stwierdzono częste występowanie choroby, prowadzącej do więdnięcia i zamierania roślin. Obiektem badań były pomidory (Lycopersicon esculentum) odmiany: Admiro, Endover, Tamimara Muchoo i Torrero, pobrane z 2 obiektów szklarniowych województwa mazowieckiego, oddalonych od siebie o około $100 \mathrm{~km}$, ale rozsada do ich produkcji pochodziła $\mathrm{z}$ tego samego źródła i posadzono ją na maty Z wełny mineralnej w ostatniej dekadzie czerwca 2013 roku. W szklarni, rośliny będące obiektem badań były niższe aniżeli pomidory zdrowe, rosnące obok, miały mniejsze liście i ich wierzchołki więdły. Do badań laboratoryjnych wybrano 20 kostek $\mathrm{z}$ porażonymi roślinami. W każdej kostce $\mathrm{z}$ wełną mineralną były po 2 rośliny. W 18 kostkach, każda $\mathrm{z}$ roślin wykazywała objawy zgnilizny podstawy, podczas gdy w 2 pozostałych symptomy występowały na jednym z pomidorów. Objawy zgnilizny były zróżnicowane. Na 3 roślinach zgnilizna występowała u nasady pędu na długości około $100 \mathrm{~mm}$ i na całym obwodzie. Na pozostałych roślinach tkanki były porażone na długości do $70 \mathrm{~mm}$ od podstawy pędu. Były one brązowe lub ciemnobrunatne, a nekroza obejmowała około $30-80 \%$ pędu. Na przekroju poprzecznym tkanki były brązowe lub brunatne na co najmniej 50\% powierzchni. Zgnilizna występowała również na około 30-70\% korzeni.

Analizę mikologiczną porażonych tkanek pędów oraz korzeni przeprowadzono stosując metodę podaną przez Orlikowskiego i Szkutę (2003). Odkażone powierzchniowo około $5 \mathrm{~mm}$ długości części tkanek pędów oraz części korzeni wykładano w szalkach Petriego o średnicy $90 \mathrm{~mm}$ na pożywkę ziemniaczano-glukozową (PDA - Potato Dextrose Agar) i inkubowano je w temperaturze $25^{\circ} \mathrm{C}$ w ciemności. W ciągu 48 godzin wyrastające $\mathrm{z}$ wyłożonych tkanek fragmenty pożywki ze strzępkami przeszczepiano na skosy z pożywką PDA. Po 10 dniach kultury segregowano i wybrane izolaty, po ich oczyszczeniu, oznaczano do gatunku na podstawie cech morfologicznych (Erwin i Ribeiro 1996). Uzyskane wyniki potwierdzono w reakcji PCR (polymerase chain reaction) ze starterami gatunkowo-specyficznymi Pn5B/Pn6 (Ippolito i wsp. 2002).

Ponadto przeprowadzono analizę mikologiczną wełny z kostek oraz $\mathrm{z}$ mat pod kostkami stosując metodę pułapkową (Orlikowski i wsp. 2011). Pobraną wełnę rozrywano na drobniejsze części, po czym wykładano ją do kuwet o wymiarach $30 \times 25 \times 5 \mathrm{~cm}$ i zalewano woda tak, aby jej lustro było powyżej $10 \mathrm{~mm}$ nad wyłożonym materiałem. Następnie do kuwet wkładano liście różanecznika odmiany Nova Zembla (po 8 sztuk) i okrywano je szczelnie folią. Po 4 dniach inkubacji w temperaturze $22-24^{\circ} \mathrm{C}$ liście wyjmowano, myto pod wodą bieżącą i destylowaną i po powierzchniowym odkażeniu ich fragmenty $\mathrm{z}$ ciemnozielonymi, nekrotycznymi plamami wykładano na pożywkę. Dalszy sposób postępowania był taki sam, jak przy analizie mikologicznej tkanek pomidora.

Ocena laboratoryjna chorobotwórczości izolatów $P$. nicotianae var. nicotianae dla pomidorów i innych roślin. W badaniach użyto metodę opisaną przez Orlikowskiego i Szkutę (2003). Pięcioma izolatami Pnn, 
wybranymi losowo spośród uzyskanych kultur tego gatunku (P1 - z porażonej podstawy pędu; P2 - z kostki $\mathrm{z}$ wełny mineralnej; $\mathrm{P} 3$ - z porażonych korzeni; $\mathrm{P} 4$ - z maty z wełny mineralnej z jednego gospodarstwa i LW5 z podstawy pędu pomidorów $\mathrm{z}$ drugiego gospodarstwa), zakażano fragmenty łodyg, korzenie, ogonki liściowe, liście i owoce odmian: Admiro, Endover, Tamimara Muchoo i Torrero umieszczonych w kuwetach o wymiarach $30 \times 25 \times 5 \mathrm{~cm}$ wyłożonych wilgotną, sterylną bibułą filtracyjną, przykrytą cienką siatką nylonową, aby uniknąć kontaktu organów roślin z wodą. Do inokulacji używano $3 \mathrm{~mm}$ średnicy fragmenty pożywki przerośniętej Pnn pobierane z brzegów 7-dniowych kultur rosnących na PDA w temperaturze $25^{\circ} \mathrm{C}$ w ciemności. W ciagu 6 dni inkubacji w temperaturze $22-24^{\circ} \mathrm{C}$ mierzono długość lub średnicę nekrozy.

Ocena wpływu temperatury na kolonizację tkanek pomidorów. Doświadczenie założono tak, jak przy ocenie chorobotwórczości izolatów Pnn dla pomidorów. Kuwety z zainokulowanymi u nasady częściami łodyg o długości około $5 \mathrm{~cm}$ wstawiono do termostatów o temperaturze od 10 do $32,5^{\circ} \mathrm{C}$ (rys. 3). Po 3 dniach inkubacji mierzono długość nekrozy.

Ocena chorobotwórczości $\boldsymbol{P}$. nicotianae var. nicotianae w warunkach szklarniowych. Do badań użyto 3-tygodniowych siewek pomidorów odmiany Admiro przygotowanych w substracie torfowym. Następnie siewki przesadzono do substratu torfowego wymieszanego $\mathrm{z}$ wełna mineralną pobraną z kostek, w których rosły pomidory z objawami zgnilizny podstawy pędu i korzeni w stosunku 1:1 w doniczkach o pojemności 0,6 litra, które ustawiono na parapecie w szklarni. Kontrolę stanowiły rośliny posadzone do niezakażonego substratu. W ciagu 2 tygodni uprawy określano liczbę roślin $\mathrm{z}$ objawami zgnilizny podstawy pędu. Po 14 dniach zmierzono długość nekrozy na pędach u podstawy.

Doświadczenia laboratoryjne założono w układzie całkowicie losowym w 4 powtórzeniach po 5 części roślin w powtórzeniu, podczas gdy szklarniowe po 10 roślin i powtórzono je 2-krotnie w odstępie 2-tygodniowym. Wyniki z przeprowadzonych doświadczeń opracowano statystycznie metodą analizy wariancji. Istotność różnic pomiędzy średnimi $(\mathrm{p}=0,05)$ oceniono testem Duncana.

\section{Wyniki i dyskusja / Results and discussion}

$\mathrm{Z}$ porażonych tkanek podstawy pędów pomidorów, pobranych z 2 gospodarstw, izolowano głównie $P$. nicotianae var. nicotianae. Gatunek ten występował na 80-100\% wyłożonych na pożywkę fragmentów pędów. Izolowano go również z korzeni. Obok tego gatunku sporadycznie izolowano Botrytis cinerea, Fusarium avenaceum oraz Penicillium spp. Pnn występował zarówno w kostkach, jak i w matach, na których ustawiona była rozsada pomidorów. Z fragmentów nekrotycznych plam na liściach różanecznika, zastosowanych jako pułapki i wyłożonych na pożywkę PDA, Pnn izolowano ze wszystkich lub z większości z nich.

Pierwsze testy nad chorobotwórczością 4 izolatów (P1-P4), uzyskanych z pomidorów pobranych z jednego gospodarstwa, wykazały ich chorobotwórczość dla części łodyg, ogonków liściowych i korzeni odmiany Admiro (rys. 1). Niezależnie od źródła izolatu i organu rośliny, tkanki były szybko kolonizowane przez Pnn. Nie stwier-

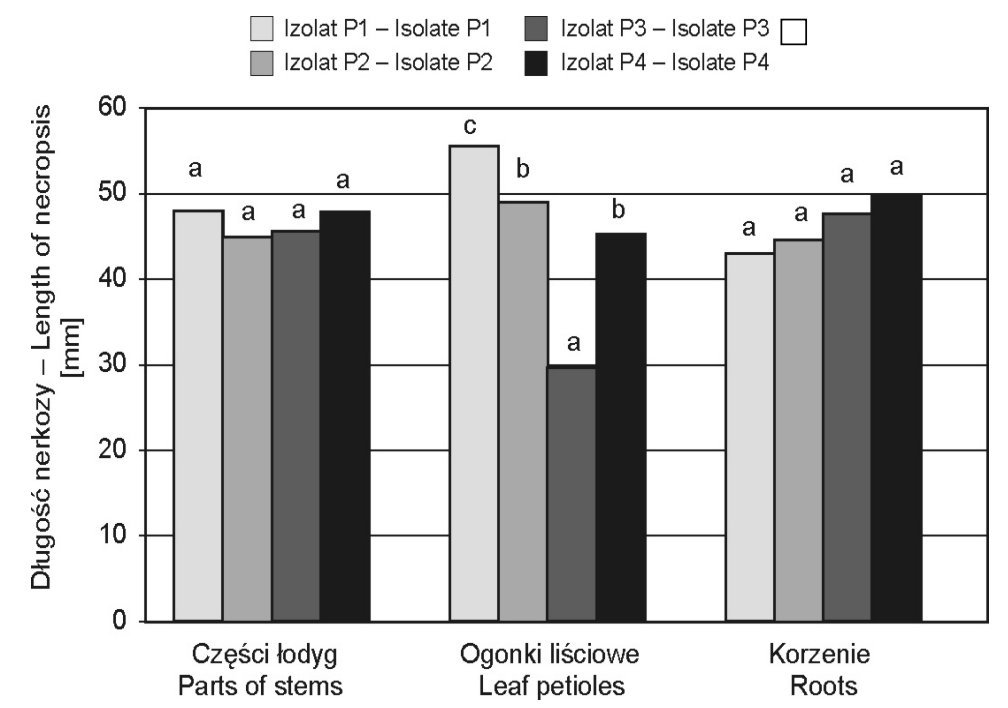

Średnie w słupkach, oznaczone ta sama litera, nie różnia się istotnie $(5 \%)$ według testu Duncana Means in columns, followed by the same letter, do not differ (5\%) according to Duncan's multiple range test

Rys. 1. Kolonizacja tkanek pomidora odmiany Admiro w zależności od źródła izolatów P. nicotianae var. nicotianae oraz organu rośliny po 6 dniach inkubacji

Fig. 1. Colonisation of tomato tissues cultivar Admiro in relation to isolate sources and cultivar organs after 6-day-incubation 


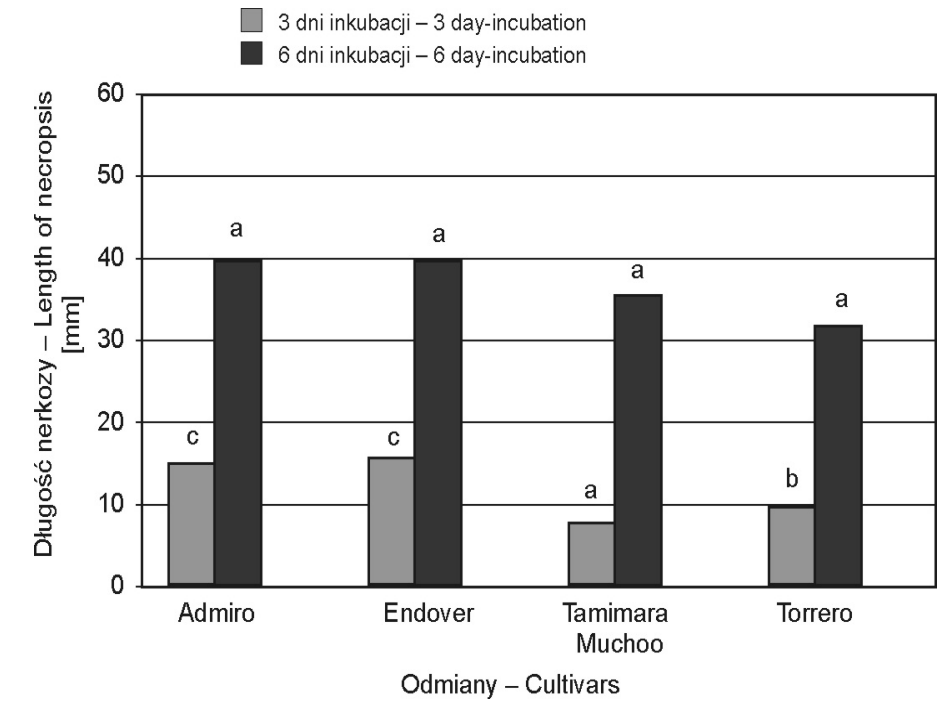

Średnie w słupkach, oznaczone ta sama litera, nie różnia się istotnie $(5 \%)$ według testu Duncana

Means in columns, followed by the same letter, do not differ $(5 \%)$ according to Duncan's multiple range test

Rys. 2. Współzależność pomiędzy odmianą pomidora, okresem inkubacji a kolonizacją części łodyg przez izolat P1 P. nicotianae var. nicotianae

Fig. 2. Relationship between tomato cultivars, incubation time and colonisation of stem parts by isolate P1 of $P$. nicotianae var. nicotianae

dzono istotnych różnic w długości nekrozy na częściach łodyg i korzeniach, natomiast wystapiły one na ogonkach liściowych. Istotnie szybciej były one kolonizowane przez izolat P1 i P2 z podstawy pędu i wełny mineralnej aniżeli $\mathrm{z}$ korzeni (rys. 1). W następnym doświadczeniu określono współzależność pomiędzy odmianami, izolatem Pnn P1 a okresem inkubacji części łodyg (rys. 2). Po 3 dniach od inokulacji nekroza wystapiła na częściach łodyg 4 odmian, przy czym najszybciej kolonizowane były odmiany Admiro i Endover, a istotnie wolniej Tamimara Muchoo i Torrero. Po następnych 3 dniach nie stwierdzono istotnych różnic w długości nekrozy, przy czym części łodyg skolonizowane były na długości 34-38 mm (rys. 2). Dane przedstawione $\mathrm{w}$ tabeli 1 . wskazują na kolonizację przez Pnn, izolat P1 liści i owoców pomidorów 4 odmian. Nekroza rozwijała się szybciej na blaszkach liściowych aniżeli na owocach, aczkolwiek po 6 dniach wielkość nekrotycznych plam wahała się od 42 do $60 \mathrm{~mm}$ (tab. 1).

Przeprowadzono również ocenę chorobotwórczości izolatu LW5 Pnn, uzyskanego $\mathrm{z}$ porażonego pędu pomidora $\mathrm{w}$ drugim gospodarstwie szklarniowym oraz jako standardu izolatu P1 z pierwszego obiektu (rys. 3). Zainokulowano nimi korzenie, części łodyg i ogonki liściowe odmiany Admiro. Niezależnie od organu rośliny, badane izolaty kolonizowały tkanki pomidorów i po 6 dniach inkubacji wielkość nekrozy wahała się od 27 do $45 \mathrm{~mm}$ (rys. 3).

Analiza współzależności pomiędzy temperaturą inkubacji a kolonizacją części łodyg pomidora po 3 dniach wykazała, że zgnilizna rozwinęła się na długości około $5 \mathrm{~mm}$ już $\mathrm{w}$ temperaturze $10^{\circ} \mathrm{C}$ przy optimum przypadającym na $30-32,5^{\circ} \mathrm{C}$ (około $45 \mathrm{~mm}$ ) (rys. 4).

Tabela 1. Kolonizacja liści (a) i owoców (b) 4 odmian pomidora przez izolat P1 P. nicotianae var. nicotianae w zależności od odmiany i czasu inkubacji

Table 1. Colonisation of tomato leaves (a) and fruits (b) of tomato by isolate P1 P. nicotianae var. nicotianae in relation to cultivars and incubation period

\begin{tabular}{l|c|c|c|c}
\hline \multirow{2}{*}{ Odmiany - Cultivars } & \multicolumn{3}{|c}{ Dni od inokulacji - Days after inoculation } \\
\cline { 2 - 5 } & \multicolumn{2}{|c|}{3} & \multicolumn{2}{c}{6} \\
\cline { 2 - 5 } & $\mathrm{a}$ & $\mathrm{b}$ & $\mathrm{a}$ & $\mathrm{b}$ \\
\hline Admiro & $17,4 \mathrm{a}$ & $15,5 \mathrm{ab}$ & $54,2 \mathrm{a}$ & $47,8 \mathrm{~b}$ \\
\hline Endover & $21,1 \mathrm{~b}$ & $15,9 \mathrm{ab}$ & $60,1 \mathrm{~b}$ & $42,1 \mathrm{a}$ \\
\hline Tamimara Muchoo & $20,4 \mathrm{~b}$ & $21,3 \mathrm{~b}$ & $57,9 \mathrm{~b}$ & $53,1 \mathrm{c}$ \\
\hline Torrero & $23,5 \mathrm{c}$ & $10,1 \mathrm{a}$ & $59,6 \mathrm{~b}$ & $42,9 \mathrm{ab}$ \\
\hline
\end{tabular}

Średnie w kolumnach, oznaczone tą samą literą, nie różnią się istotnie (5\%) według testu Duncana

Means in columns, followed by the same letter, do not differ $(5 \%)$ according to Duncan's multiple range test 


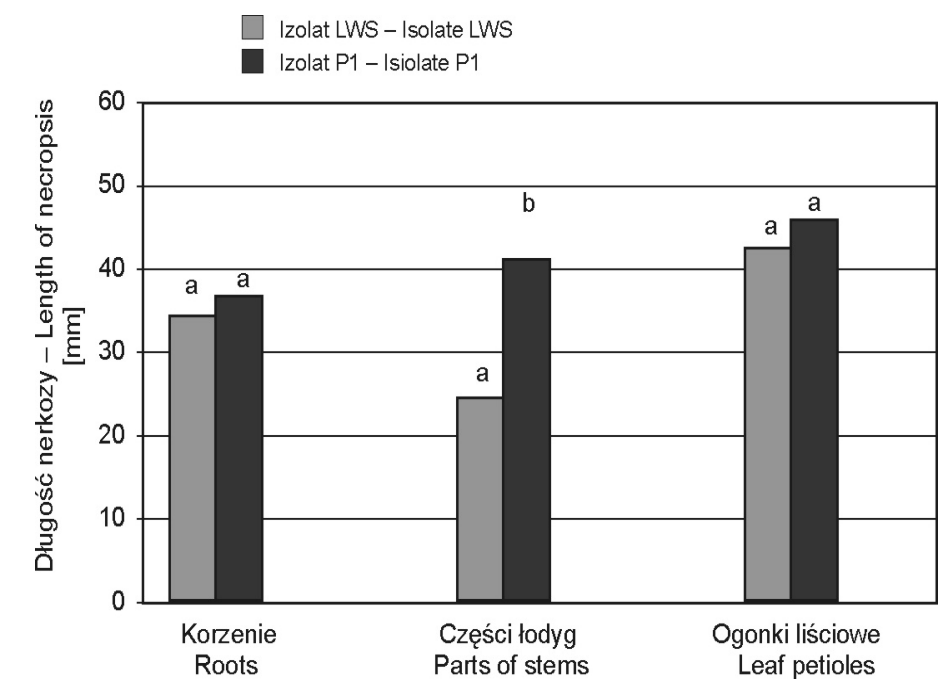

Średnie w słupkach, oznaczone tą samą litera, nie różnią się istotnie $(5 \%)$ według testu Duncana Means in columns, followed by the same letter, do not differ (5\%) according to Duncan's multiple range test

Rys. 3. Współzależność pomiędzy organami pomidorów odmiany Admiro a ich kolonizacją przez izolaty P. nicotianae var. nicotianae pochodzących z 2 gospodarstw po 6 dniach inkubacji

Fig. 3. Relationship between tomato organs cultivar Admiro and their colonization by isolates of P. nicotianae var. nicotianae from 2 greenhouse farms after 6-day-incubation

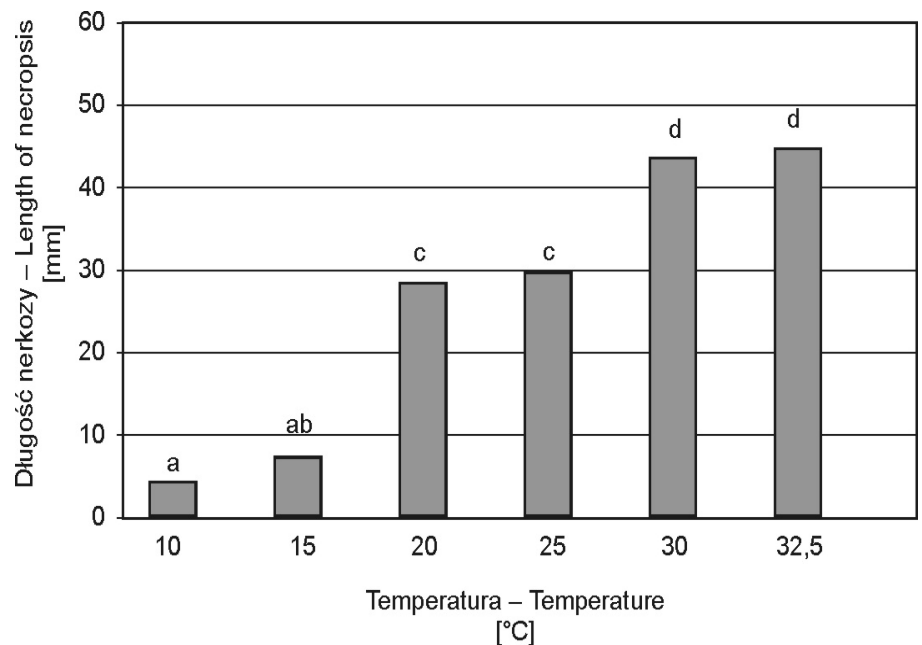

Średnie w słupkach, oznaczone tą samą litera, nie różnią się istotnie $(5 \%)$ według testu Duncana Means in columns, followed by the same letter, do not differ (5\%) according to Duncan's multiple range test

Rys. 4. Kolonizacja części łodyg pomidora odmiany Admiro przez izolat P1 P. nicotianae var. nicotianae po 3 dniach inkubacji w zależności od temperatury

Fig. 4. Colonization of tomato cultivar Admiro stem parts by isolate P1 P. nicotianae var. nicotianae after 3 days incubation in relation to temperature

W doświadczeniu szklarniowym na pomidorach posadzonych do torfu $\mathrm{z}$ zakażoną wełną mineralną, pierwsze objawy więdnięcia siewek pojawiły się po 3 dniach, a po 8 dniach niemal wszystkie rośliny zwiędły (tab. 2). Patogen spowodował zgniliznę pędu na długości do $30 \mathrm{~mm}$ od podstawy. Szybkiemu rozwojowi choroby sprzyjała temperatura dochodzaca do $30^{\circ} \mathrm{C}$.

Uzyskane dane wskazuja, że obok $P$. cryptogea, stwierdzonego na pomidorach szklarniowych w 2007 roku (Ptaszek i Orlikowski 2008), istnieje zagrożenie roślin również przez $P$. nicotianae var. nicotianae. Pierwszy z gatunków jest przyczyną zamierania korzeni pomidorów, podczas gdy drugi $\mathrm{z}$ nich powoduje również zgniliznę podstawy pędu. Na podstawie występujących objawów można sugerować, z jakim gatunkiem patogena mamy do czynienia. Przy sadzeniu pomidorów w 3. dekadzie czerwca istnieją bardzo sprzyjające warunki do rozwoju Pnn. Szczególnie istotna jest temperatura, często optymalna lub zbliżona do optymalnej dla rozwoju patogena. $\mathrm{Z}$ badań Flett i Ashcroft (1997) wynika, że jest to $25-28^{\circ} \mathrm{C}$, 
podczas gdy Grote i Claussen (2001) uważają, że jest to $30-35^{\circ} \mathrm{C}$. Badania własne wskazują na $30-32,5^{\circ} \mathrm{C}$ jako temperaturę najbardziej sprzyjającą rozwojowi patogena.

Tabela 2. Rozwój zgnilizny podstawy pędu siewek pomidora odmiany Admiro rosnących w podłożu zakażonym przez izolat P1 P. nicotianae var. nicotianae (Pnn); liczba siewek $\mathrm{z}$ objawami zgnilizny podstawy w doświadczeniu szklarniowym $(\mathrm{n}=10)$

Table 2. Spread of stem base rot on tomato seedlings cultivar Admiro growing in peat with stonewool infested with isolate P1 P. nicotianae var. nicotianae (Pnn), number of diseased seedlings $(\mathrm{n}=10)$

\begin{tabular}{l|c|c|c}
\hline \multirow{2}{*}{$\begin{array}{c}\text { Kombinacje } \\
\text { Treatments }\end{array}$} & \multicolumn{3}{|c}{$\begin{array}{c}\text { Dni od sadzenia } \\
\text { Days after planting }\end{array}$} \\
\cline { 2 - 4 } & 3 & 5 & 8 \\
\hline Kontrola - Control & $0 \mathrm{a}$ & $0 \mathrm{a}$ & $0 \mathrm{a}$ \\
\hline $\begin{array}{l}\text { Substrat zakażony } \\
\text { przez Pnn }\end{array}$ & $1,5 \mathrm{~b}$ & $9,3 \mathrm{~b}$ & $9,8 \mathrm{~b}$ \\
$\begin{array}{l}\text { Substratum infested } \\
\text { with Pnn }\end{array}$ & & & \\
\hline
\end{tabular}

Średnie w kolumnach, oznaczone tą samą literą, nie różnią się istotnie (5\%) według testu Duncana

Means in columns, followed by the same letter, do not differ (5\%) according to Duncan's multiple range test

W obecności wody, w kostce $\mathrm{z}$ wełną mineralną, na strzępkach przerastających łodygę i korzenie tworzą się zarodnie pływkowe, z których nawet przy niewielkim spadku temperatury uwalniają się zoospory. O ich obecności W środowisku uprawy pomidorów świadczy ich wykrycie nie tylko na porażonych łodygach i korzeniach, ale również $\mathrm{w}$ kostkach $\mathrm{i}$ matach wełny mineralnej. Powtarzające się cykle tworzenia zoosporangiów i uwalniania zoospor powodują wzrost inokulum patogena, infekcję kolejnych korzeni i wiązek przewodzących (Flett i Ashcroft 1997) oraz drastyczne ograniczenie przewodzenia wody i soli mineralnych z podłoża do części nadziemnych. Uzyskane dane wskazują na możliwość kolonizacji przez patogena wszystkich organów pomidora i w warunkach optymalnych bardzo szybki rozwój choroby. W ciagu doby gatunek ten może skolonizować tkanki na długości powyżej $8 \mathrm{~mm}$. Powstaje pytanie o źródło czynnika chorobotwórczego w obu gospodarstwach? Poza pomidorami nie uprawia się $\mathrm{w}$ nich innych gatunków roślin, a do nawożenia i podlewania używa się wody wodociągowej lub ze studni głębinowej, wolnej od Pnn. W obu obiektach szklarniowych dotychczas nie występowały choroby podstawy pędu i korzeni. Prawdopodobnym źródłem patogena są sadzonki, o czym świadczy również pojawienie się objawów chorobowych na roślinach w różnych miejscach hal produkcyjnych. Wystappienie zgnilizny podstawy pędu i korzeni w obiektach szklarniowych, to straty dochodzące do co najmniej $25 \%$. Ponadto dla uniknięcia wystąpienia choroby $\mathrm{w}$ następnym cyklu produkcyjnym istnieje konieczność wymiany mat $\mathrm{z}$ wełną mineralną oraz bardzo dokładnego odkażenia hal produkcyjnych. Wiąże się to dodatkowo ze znacznymi kosztami ponoszonymi na przygotowanie szklarni do kolejnego cyklu uprawy.

\section{Wnioski / Conclusions}

1. $P$. nicotianae var. nicotianae (Pnn) okazał się najczęściej izolowanym gatunkiem $\mathrm{z}$ pomidorów szklarniowych wykazujących objawy zgnilizny podstawy pędu i korzeni.

2. Badania nad chorobotwórczością 5 izolatów tego gatunku wykazały, że kolonizowały one wszystkie organy pomidorów, niezależnie od odmiany, przy czym nekroza rozwijała się najszybciej na ogonkach liściowych.

3. Omawiany gatunek kolonizował tkanki pomidorów w zakresie temperatury od 10 do $32,5^{\circ} \mathrm{C}$ przy optimum $30-32,5^{\circ} \mathrm{C}$.

4. W warunkach szklarniowych, na siewkach pomidorów rosnących w podłożu zakażonym przez Pnn, pierwsze objawy zgnilizny podstawy pędu pojawiły się po 3 dniach, a po tygodniu większość roślin zamarło.

5. Uzyskane dane wskazują na Pnn jako jednego z najgroźniejszych patogenów pomidorów szklarniowych.

\section{Podziękowania / Acknowledgements}

Autorzy dziękują mgr Aleksandrze Trzewik za pomoc w identyfikacji molekularnej P. nicotianae var. nicotianae oraz Renacie Filutowskiej i Urszuli Łazęckiej za pomoc techniczną w realizacji doświadczeń.

\section{Literatura / References}

Boczek J., Brzeski M., Czyżewska S., Kagan F., Leski B., Macias W., Narkiewicz-Jodko J., Nawrocka B., Rondomański W., Ślusarski Cz., Szwejda J. 1985. Szkodniki i choroby roślin warzywnych. PWRiL, Warszawa: 210-213.

Bruna A.V., Tobar G.C. 2004. Identification of Phytophthora nicotianae, causal agent of tomato stem canker in Chile. Agric. Técnica 64 (3): 314-318.

Elena K. 2000. Pathogenicity of Phytophthora nicotianae isolates to tobacco and tomato cultivars [Nicotiana tabacum L. - Lycopersicon esculentum Mill.]. Phytopathol. Mediterr. 39 (2): 245-250.

Erwin D.C., Ribeiro O.K. 1996. Phytophthora Disease Worldwide. APS Press, St. Paul, MN, 562 pp.

Flett S.P., Ashcroft W. 1997. Phytophthora root rot of tomatoes. Agric. Notes 12: 1-2.

Grote D., Claussen W. 2001. Severity of root rot of tomato plants caused by Phytophthora nicotianae under nutrient- and light stress conditions. Plant Pathol. 50: 702-707. 
Hoy M.W., Ogawa J.M., Duniway J.M. 1984. Effects of irrigation on buckeye rot of tomato fruit caused by Phytophthora parasitica. Phytopathology 74: 474-478.

Ippolito A., Schena L., Nigro F. 2002. Detection of Phytophthora nicotianea and P. citrophthora in citrus roots and soil by nested PCR. Eur. J. Plant Pathol. 108 (9): 855-868.

Orlikowski L.B., Ptaszek M., Trzewik A., Orlikowska T. 2011. Przydatność pułapek liściowych do detekcji Phytophthora z wody. Sylwan 155: 493-499.

Orlikowski L.B., Szkuta G. 2003. First notice of Phytophthora tip blight on Picea omorika and Thuja occidentalis in Poland. Phytopathol. Pol. 28: 63-67.

Price T.V., Maxwell M.K. 1980. Studies of disease problems and their control in hydroponics in Australia. Acta Hortic. 98: 307-316.

Ptaszek M., Orlikowski L.B. 2008. Phytophthora cryptogea, nowy pathogen pomidorów szklarniowych uprawianych w wełnie mineralnej. Zesz. Probl. Post. Nauk Rol. 529: 155-159.

Ślusarski Cz. 2005. Studia nad plonotwórczą efektywnością ochrony pomidora szklarniowego przed patogenami glebowymi w wielokrotnie użytkowanej wełnie mineralnej. Rozprawa habilitacyjna. Instytut Warzywnictwa, Skierniewice, 103 ss.

Waterhouse G.M., Waterston J.M. 1964. Phytophthora nicotianae var. nicotianae. Commonw. Mycol. Institute. Description of pathogenic fungi and bacteria $35: 1-2$.

Weststejn G. 1973. Phytophthora nicotianae var. nicotianae in tomatoes in the Netherlands. Neth. J. Plant Pathol. 79: 36-40.

Zinnen T.M. 1988. Assessment of plant diseases in hydroponic culture. Plant Dis. 72 (2): 96-99. 